\title{
O Direito Brasileiro no Exterior
}

ARNOLD WALD

\begin{abstract}
R ecebemos da Dra. Simonne F. Topcha, advogada em Paris, um fascículo dos Jurisclasseurs que ela publicou sôbre o direito brasileiro. São trinta páginas de estudos minuciosos e de inteligente tradução da nossa legislação que assim passa a ter msior divulgação no velho mundo. Além do trabalho realizado pelos tratados gerais de direito comparado como os de René David ou de Arminjon, Nolde e Wolff, os pequenos esforços individuais dos pesquisadores não devem ser desprezados e pensamos que se trata no caso da melhor das difusões culturais.
\end{abstract}

Assistimos, em certo sentido, a elaboração do trabalho da Dra. Topcha. Estavamos em Paris, como bolsista extraordinário do govêrno francês, em 1954, quanco fomos convidados pelo Professor René David, catedrático de direito comparado da Faculdade de Paris, a assistir a uma das suas aulas no curso de doutorado. Lá fomos em companhia de uma jovem economista de São Paulo, interessada em questões jurídicas, Maria José de Carvalho Vilela. Era o fim do curso e os estudantes escolhiam as matérias para a prestaçäo dos exames finais. Foi um prazer para nós saber que entre essas matérias, ao lado do direito russo e do direito árabe, houvesse quem tivesse escolhido o direito da familia brasileira. E a Dra. Topcha pediu alguns esclarecimentos sôbre o reconhecimento de filhos adulterinos em nosso direito. A pedido do Professor David, esclarecemos as dúvidas surgidas e soubemos da próxima publicação do estudo que acaba de sair.

Tínhamos feito, por conta própria, o balanço dos livros jurídicos brasilairos existentes nas diversas bibliotecas de Paris. Na realidade, muito pouca coisa havia, devendo todavia ser assinalada a presença de uma coleção completa da Revista Forense na Société de Législation Comparée e a existência de diversas obras básicas em nosso direito dos Professores Haroldo Valladão, Temístocles Cavaicanti e outros. Mas a bibliografia em geral era parca. Fizemos para a Faculdade de Direito da Universidade de Paris uma lista de obras iurídicas brasileiras cuja aquisição seria interessante. Parece-nos todavia que o esfôrço de divulgação há de ser bilateral. Também, no Brasil, poderíamos fazer alguma coisa para difundir e fazer conhecer os nossos trabalhos e o nosso direito. O Profesšcr Escarra, catedrático de direito comercial da Faculdade de Paris e diretor da Revue Trimestrielle de Droit Comercial se queixou por não encontrar em Paris o nosso Código Comercial e assim por diante. Por um lado as instituiçôes oficiais poderiam, por meio de doação ou de in- 
tercâmbio, facilitar a aquisição de livros brasileiros no exterior. Por outro lado, as revistas brasileiras e os nossos autores poderiam mandar um ou do exemplares às bibliotecas ou às revistas a fim de permitir o conhecimento do direito brasileiro pelos interessados. O Instituto Brasileiro de Direito Comparado e Estudos Legislativos remete trimestralmente para diversas revistas européias, entre as quais os Cadernos de Bibliografia e de Legislação da América Latina, dirigidos pelo Dr. Sola Canizares, uma lista das obras publicadas no Brasil. Necessário seria que também os livros e revistas pudessem nor exemplo ser centralizados na França no Société de Legislation Comparée facilitando assim os trabalhos dos estudiosos que como a Dra. Topcha, quisessem conhecer o nosso direito para a maior irradiação da nossa cultura

O triste espetáculo do administrador empírico, em luta com os complexos problemas que hodiernamente assoberbam o Estado, sugere a situação de um desventurado aprendiz de violino que, em vez de arco, usasse um serrote e, ainda por cima, calçasse luvas de boxe para fazer os exercícios.

Benedicto Silva - Assistência Técnica em Adrrinistração Pública, R.S.P., dez. ${ }^{\circ} 1951$. 